ks. Czesław Rychlicki

UMK Toruń

\title{
Tożsamość sakramentalnego misterium w przymierzu Chrystusa z Kościołem i w małżeństwie
}

„Dlatego opuści człowiek ojca i matkę, a połaczy sięz żona swoją, i będa dwoje jednym ciałem. Tajemnica to wielka, a ja mówię: $w$ odniesieniu do Chrystusa i do Kościoła" (Ef 5,31-32)

\section{Małżeństwo - rzeczywistość ziemska i misterium zbawcze}

\subsection{Małżeństwo - rzeczywistość naturalna}

Małżeństwo jest instytucją naturalną stanowioną przez związek mężczyzny i kobiety od początku najstarszych kultur. W wielu starożytnych kulturach instytucja ta była cywilnie chroniona. I tak np. starożytne prawo rzymskie oświadczało: „Małżeństwo jest związkiem zawartym na całe życie między mężczyzną i kobietą, w którym obydwie strony podlegają tym samym prawom: boskiemu i ludzkiemu" ${ }^{1}$.

Już w tym kontekście prawa cywilnego znajdujemy ogólne odniesienie instytucji małżeństwa także do prawa boskiego, którego podstawy są zawarte w Starym i Nowym Testamencie. Księga Rodzaju zwraca uwage na wyraźnie personalistyczny sens określeń

\footnotetext{
1 Por. „Nuptiae sunt conjunctio maris e feminae et consortium omnis vitae, divini et humani juris communicatio", V. Modestino, Libro 1 Regularum, nel Digesto, Lib. 23, 2, De ritu nuptiarum, 1 , $m$, cyt. za: P. HAFfner, Il mistero sacramentale, Città del Vaticano 2002, s. 210.
} 
człowieka powołanego przez Stwórcę do istnienia na „obraz i podobieństwo Boga”, w wydaniu mężczyzny i kobiety: „A wreszcie rzekł Bóg: «Uczyńmy człowieka na Nasz obraz, podobnego Nam. [...]». Stworzył więc Bóg człowieka na swój obraz, na obraz Boży go stworzył: stworzył «mężczyznę i niewiastę»" (Rdz 1, 26-27).

Stworzenie człowieka w zróżnicowanym seksualnie wydaniu mężczyzny i kobiety jest jednocześnie potwierdzeniem tej samej godności człowieczej w obu podmiotach: „Stworzył Bóg "człowieka» na swój obraz [...] «mężczyznę i niewiastę»" (Rdz 1, 27). Na zasadzie tej samej równości osób Stwórca zleca obu stronom panowanie nad ziemią (por. Rdz 1, 28-29), a zwłaszcza współtwórczy udział z Nim samym w rozwijaniu gatunku ludzkiego przez udzielony obojgu dar płodności: „Bądźcie płodni i rozmnażajcie się [...]” (Rdz 1, 28). Ten dar udzielony przez Boga parze ludzkiej stanowi przedmiot jej istotnego powołania i cel stworzenia człowieka w zróżnicowanym wydaniu seksualnym.

Człowiek został stworzony na obraz i podobieństwo Boga jako „mężczyzna i kobieta”, pozostający we wzajemnym odniesieniu osobowym. Obraz Boży w człowieku odnosi się więc jednoznacznie do mężczyzny i niewiasty, z czego wynika, że zróżnicowanie płciowe stanowi dar udzielony człowiekowi w samym akcie stworzenia. Dlatego nieuzasadnione byłoby pojmowanie zróżnicowania seksualnego jako konsekwencji pierwszego upadku grzechowego, jak to głosiły niektóre mitologie starożytne.

W świetle Objawienia wyraźnie jawi się prawda, że seksualne zróżnicowanie człowieka w wydaniu mężczyzny i kobiety oraz ich wzajemne odniesienie przynależą do odwiecznego planu Stwórcy. Stąd więc seksualne zróżnicowanie człowieka jako mężczyzny i kobiety jest istotną i właściwą formą jego istnienia, obejmującą całą osobę człowieka a nie tylko jego naturę fizyczną. Takie ujęcie osoby ludzkiej w jej zróżnicowanym wydaniu mężczyzny i kobiety znajduje jasne potwierdzenie w decyzji Stwórcy, który po stworzeniu człowieka sam ocenił ten akt jako „bardzo dobry”: „A Bóg widział, że wszystko, co uczynił, było bardzo dobre” ( $\operatorname{Rdz} 1,31)$. 
Opierając się na Objawieniu biblijnym należy przyjąć, że nie ma żadnych podstaw do negatywnego rozumienia i traktowania seksualności, jak to czynili m.in. manichejczycy. Jest ona bowiem darem Boga udzielonym człowiekowi w jego trwałym istnieniu historycznym i wskazuje na konkretny podmiot osobowy, jakiemu ten dar został udzielony. Tym podmiotem są „mężczyzna i kobieta” w ich zróżnicowanych wymiarach, ze wskazaniem im prawa korzystania z tej sfery w zakresie prokreacji i kontynuowania historii: „Po czym Bóg im błogosławił, mówiąc do nich: «Bądźcie płodni i rozmnażajcie się, abyście zaludnili ziemię i uczynili ją sobie poddaną»" ( $\operatorname{Rdz} 1,28)$. Powołanie do istnienia człowieka w zróżnicowaniu seksualnym przez Boga nie zakłada dywinizacji seksu i pozostaje zawsze rzeczywistością stworzoną i ziemską, stanowiącą integralny element osoby ludzkiej w jej życiu doczesnym.

Cytowany wyżej tekst Rdz 1, 28 zwraca szczególną uwagę na „płodność”, do jakiej mężczyzna i kobieta są wezwani przez Stwórcę. Jawi się ona wyraźnie jako dar Boga i owoc Jego błogosławieństwa. Dlatego płodność, integralnie związana ze zróżnicowaną seksualnością mężczyzny i kobiety, znajduje swoje źródło w Bogu, Stwórcy człowieka. Skoro seksualność mężczyzny i kobiety oraz ich wzajemna miłość prowadząca do płodności mają swoje źródło w Bogu Stwórcy i Jego błogosławieństwo, to również w Nim jest źródło świętości małżeństwa. Tak ukazana w świetle Objawienia rzeczywistość małżeństwa, jednoczącego w sobie zróżnicowanie seksualne mężczyzny i kobiety i ich wzajemną miłość prowadzącą do płodności, uświęca związek małżeński i wzywa jednoznacznie do trwania w małżeństwie monogamicznym: „Dlatego to mężczyzna opuszcza ojca swego i matkę swoją i łączy się ze swą żoną tak ściśle, że stają się jednym ciałem" (Rdz 2, 24; Ef 5, 31).

Spotkanie mężczyzny i kobiety w miłości prowadzącej do stania się niejako „jednym ciałem” jest po prostu wyrazem przyjęcia przez małżonków daru pochodzącego od Boga, który przynależy do struktury małżeństwa. Jakkolwiek zjednoczenie małżonków w „jednym ciele” ma na uwadze także cel prokreacyjny, to nie ogranicza się jedynie do niego. Cel jest głębszy, bo jest ustawiony na osobową wspólnotę obu 
stron, która powinna je prowadzić do jedności nie tylko fizycznej, ale obejmującej w pełni wszystkie sfery osobowego postępowania człowieka, jego umysł i wolę. Takie zjednoczenie mężczyzny i kobiety w małżeństwie pozostaje w ścisłej relacji do Bożego zamysłu, powołującego człowieka w wydaniu mężczyzny i kobiety na „obraz i podobieństwo Stwórcy” dla jedności między nimi przez dar im ofiarowany. Struktura odmienności ich ciała ma odpowiedzieć owemu wezwaniu Stwórcy na ofiarowanie siebie drugiej osobie i przyjęcie przez nią daru jej ofiarowanego. Akt wzajemnego ofiarowania siebie nie ma jedynie wymiaru fizycznego, ale prowadzić ma do jedności osobowej. Takie rozumienie wskazuje na personalizujący charakter jedności cielesnej między mężczyzną i kobietą, która pozostaje w relacji do ich zadania nie tylko prokreacyjnego, ale także do doskonalenia własnej osobowości².

Biblijny przekaz prawdy o stworzeniu człowieka w wydaniu mężczyzny i niewiasty oraz powołaniu ich do płodności i wzajemnej miłości, aż do osobowego zjednoczenia w ,jednym ciele” (por. Rdz 1,25-28; 2,24), stanowi podstawowe tło dla struktury małżeństwa jako naturalnej rzeczywistości powołanej „od początku” przez Stwórcę. Do tego pierwotnego wzoru odwołuje się sam Chrystus w odpowiedzi na postawione przez faryzeuszy pytanie w kwestii rozwodu. W odpowiedzi swej Jezus podkreśla, że małżeństwo ustanowione przez Stwórcę „od początku” jako związek mężczyzny i kobiety, pozostaje związkiem „monogamicznym” i „nierozerwalnym”: „Czyż nie czytaliście, że Stwórca od początku stworzył ich jako mężczyznę i kobietę? [...] Dlatego opuści człowiek ojca i matkę i złączy się ze swoją żoną, i będą oboje jednym ciałem. A tak już nie są dwoje, lecz jedno ciało. Co więc Bóg złączył, niech człowiek nie rozdziela” (Mt 19, 4-6).

Z tej odpowiedzi Jezusa wynika, że jedność cielesna między mężczyzną i kobietą została ujęta w planie Bożym w formie małżeństwa. Dlatego małżeństwo nie może być pojmowane jako samowolnie kształtowana jedność ludzka, ale jako skutek Bożego planu. Jest to argument, że sam Bóg zaprogramował współpracę w powoływaniu do

2 Por. P. Grelot, La coppia umana nella Sacra Scrittura, Milano 1968, s. 26-33. 
istnienia nowe istoty ludzkie przez płciowe zróżnicowanie człowieka w małżeństwie monogamicznym i nierozerwalnym ${ }^{3}$.

Skoro sam Chrystus wyjaśnia, że małżeństwo nie jest jedynie instytucją ludzką, ale stanowi podstawowy element stwórczego planu Boga, to należy uznać, że jest ono rzeczą świętą, zaprogramowaną przez samego Boga jako szczególny człon tego planu odnośnie tożsamości mężczyzny i kobiety, a więc jako powołanie wpisane w ich naturę ${ }^{4}$.

\subsection{Małżeństwo - misterium zbawcze}

Podkreślając naturalny charakter małżeńskiego związku mężczyzny i kobiety, wpisany w ich naturę „od początku” przez Stwórcę, pisma Starego Testamentu nie zacierają jego wymiaru zbawczego. Teologia ujmuje ten wymiar w kategorii sakramentu, jako znaku osobowego spotkania człowieka z Bogiem w Chrystusie, prowadzącego do wejścia w nadprzyrodzony kontakt $\mathrm{z}$ Bogiem przez Jego łaskę, która jest miłością. Termin „sakrament”, stosowany na określenie siedmiu rytów zbawczych w życiu Kościoła, nie występuje jednak w Biblii. Natomiast w Nowym Testamencie, zwłaszcza w pismach św. Pawła, występuje termin „mysterion - tajemnica” (por. Ef 3; Kol 1), który ogólnie oznacza „ukryty, zbawczy plan Boga na korzyść człowieka, ujawniony w czasach ostatecznych w Chrystusie Jezusie i rozwijany w historii Kościoła" ${ }^{5}$. Rozumienie sensu tego terminu zależy w dużej mierze od znaczenia, jakie się nada terminowi „mysterion” 6 .

3 Por. G. Concetti, La relazione della coppia, w: Giovanni Paolo II, Catechesi sul matrimonio, Roma 1980, s. 45-59.

4 Por. C. Rocchetta, Il Sacramento della coppia. Saggio di teologia del matrimonio cristiano, Bologna 1996, s. 27-28

5 Por. B. Neunheuser, Mysterium (mysterion), w: LThK t. 7, Freiburg 1968, kol. 727-731; J. Auer, J. Ratzinger, Il mistero dell' Eucaristia, Cittadella - Assisi 1989, s. 59-70; G. BARTH, Sakrament, w: Encyklopedia Katolicka, t. 17, Lublin 2012, kol. 891-894.

6 Por. G. Bornkamm, Mysterion, myéo, w: ThW IV, kol. 809-834; R. Schulte, Il mysterion nel Nuovo Testamento, w: Mysterium Salutis, t. IV/2, Brescia 1975, s. 8285; R. Penna, Il “mysterion" paolino. Traiettoria e costituzione, Brescia 1978, s. 51. 
Termin „mysterion” pochodzi od słowa „myein” i pierwotnie oznaczał „zamknąć” (np. usta) i stąd etymologicznie oznaczał coś sekretnego i ukrytego. Z kolei, w Ewangeliach synoptycznych oznacza on „tajemnicę Królestwa Bożego” a także samego Jezusa jako Mesjasza. Wreszcie, posiada on także aspekt prawniczy, w sensie wezwania do opowiedzenia się na rzecz wiary ${ }^{7}$. W tym wieloznacznym rozumieniu terminu „mysterion” przeważa jeden sens, zawarty w Ewangelii św. Marka (1, 15): „Czas się wypełnił i bliskie jest Królestwo Boże. Nawracajcie się i wierzcie w Ewangelię”. W tej wypowiedzi Jezusa termin „mysterion” oznacza objawioną tajemnicę Chrystusa i Jego dzieła ${ }^{8}$.

Rozwój znaczenia terminu „mysterion” następuje w listach do Efezjan i Kolosan, w których Apostoł używa tego określenia w sensie pogłębionej już „tajemnicy” w historycznym rozwoju Kościoła i oznacza on Chrystusa, jako powszechną przyczynę jedności i chwały: „Jest nią Chrystus pośród was - nadzieja chwały” (Kol 1,27). To odniesienie sensu „mysterion” do Chrystusa, jako przyczyny jedności, pozostaje w ścisłej łączności z „mysterion” - „sakramentalnością” małżeństwa, sugerowaną w Ef 5, 21-33.

Pozostając w nurcie podstawowej w Starym Testamencie idei „przymierza” w ukazywaniu ścisłych relacji między Bogiem i Narodem wybranym, a ogólnie z człowiekiem stworzonym na „obraz i podobieństwo Boże” (Rdz 1, 26-27), św. Paweł podejmuje tę ideę i rozwija ją. U jej początków jest Księga Rodzaju, która prezentując opisy stworzenia nie zatrzymuje się na fakcie stworzenia świata i człowieka, ale ukazuje Boga Stwórcę - transcendentnego wobec całego stworzenia i bliskiego człowiekowi - jako wchodzącego w relację przymierza miłości. Refleksja Izraela nad historią początków i zbawczą dla narodu wybranego ingerencją Boga w jego dzieje prowadzi do rozwoju wiary Izraela w przymierze, osiągając swój wysoki punkt w Abrahamie. Istotnymi momentami w rozwoju tej wiary Izraela jest świadomość

\footnotetext{
7 Por. R. Schulte, I singoli sacramenti come articolazione del sacramento radicale, w: Mysterium Salutis, t. IV/2, Brescia 1975, s. 89-97.

8 Por. C. Rychlicki, Sakramentalny charakter przymierza małżeńskiego. Studium teologiczno - dogmatyczne, Płock 1997, s. 106-107.
} 
jego wolnego wyboru przez Boga i zbawcze doświadczenie „wyjścia”. Przykładem tej wiary jest Księga Rodzaju, która opisując historię „początków” pozwala dostrzec faktycznie realizowane przymierze Boga z człowiekiem, odpowiadające rozumieniu tej relacji zbawczej przez Izrael (por. Rdz 2, 4) 9 .

Pozostając w granicach tematu wyznaczającego naszą refleksję, należy odwołać się do przepowiadania prorockiego, które w temat przymierza wprowadza istotny, $\mathrm{z}$ antropologicznego punktu widzenia dla historii przymierza temat małżeństwa, jakie stanowi przymierze („berît”) między mężczyzną i kobietą. Tym obrazem ludzkiego przymierza w małżeństwie posługują się prorocy dla przedstawienia nadprzyrodzonego obrazu przymierza Boga z ludzkością, będącego archetypem przymierza małżeńskiego. Prawny aspekt tego przymierza wypływa z podstawowych elementów stanowionych przez: „miłość”, „wierność”, „więź uczuciową”. Tę rzeczywistość przymierza odnajdujemy u proroków ukazaną w dwóch aspektach: przymierza „niedoskonałego” i „eschatologicznego”. Przykładem pierwszego jest „przymierze Synaickie”, w którym doświadczenie miłości postrzegane od strony ludzkiej: „naród - oblubienica”, przypomina zranioną miłość małżeńską przez przeciwieństwa losu i inne niebezpieczeństwa, jak cudzołóstwo i prostytucję. Drugi aspekt przymierza to doskonałe przymierze „eschatologiczne”, w którym miłość odnajdzie swoje właściwe oblicze powracając do swego prototypu w miłości rajskiej, niemożliwej do osiągnięcia bez łaski odkupieńczej. W tej eschatologicznej perspektywie miłość ludzka, przeżywana w sakramencie małżeństwa uświęcającego także jego aspekt seksualny, odnajdzie swoje istotne właściwości: zjednoczenie w miłości, płodność i nierozerwalność. Jest to więc ideał, do którego powinna podążać para małżeńska wzorując się nie tylko na pierwotnym prototypie stanowionym przez pierwsze małżeństwo opisane w Biblii, ale na swoim Boskim archetypie. Jest to działanie możliwe do osiągnięcia celu, pod

9 Por. A. Schőkel, Motivos sapienciales y de alianza en Gen 2-3, Biblica 43 (1962), s. 285-316. 
warunkiem uczestnictwa w łasce Odkupiciela odradzającej małżeństwo zaplanowane przez Stwórcę ${ }^{10}$.

Idea „przymierza miłości” została podjęta i rozwinięta w Nowym Testamencie w dwóch aspektach: 1) Przymierze miłości Chrystusa z Kościołem i 2) Przymierze miłości małżeńskiej. Pisarze Nowego Testamentu w charakteryzowaniu osób zawierających małżeństwo stosują dwa zespoły określeń: „mężczyzna - kobieta (aner-gine; arsen-thelus)” i „oblubieniec - oblubienica (nymfios-nymfe)”. Obydwa zestawy określeń posiadają zróżnicowane zastosowanie. Jest sprawą znamienną, że w tekstach Nowego Testamentu, odnoszących się do osób stanowiących małżeństwo, jest prawie zawsze pominięty sens seksualny związany z nimi, z wyjątkiem zarzutów kierowanych przez Pawła pod adresem pogan za popełniane przez nich aberracje (por. Rz 1,18-32). Jest to znaczna różnica względem Starego Testamentu, gdzie na ogół terminy „mężczyzna - (zakar) i niewiasta (neqebah)” prawie zawsze są używane w połączeniu ze zróżnicowaniem płciowym ${ }^{11}$.

W Ewangeliach i w nauczaniu apostolskim najczęściej stosowaną terminologią w odniesieniu do małżeństwa są określenia: „aner gine", które podkreślają wyjątkowy charakter tej instytucji ziemskiej i naturalnej, jaka po zmartwychwstaniu nie miałaby dotychczasowego znaczenia. Taką interpretację może sugerować wypowiedź Jezusa: „Przy zmartwychwstaniu bowiem nie będą się ani żenić, ani za mąż wychodzić, lecz będą jak aniołowie Boży w niebie” (Mt 22,30) ${ }^{12}$.

Ziemski i naturalny wymiar małżeństwa podkreślają także terminy „nymfios - nymfe”: „oblubieniec - oblubienica”, które normalnie odnoszą się do małżeństwa jako instytucji ziemskiej (por. Mt 10,35). W pewnych jednak sytuacjach terminy te odnoszą się tylko do Chrystusa i Kościoła, na co wskazuje wypowiedź Jezusa o sobie samym:

\footnotetext{
10 Por. P. Grelot, La coppia umana nella Sacra Scrittura, Milano 1968, s. 60-62. 11 Por. N. M. Loss, Il tema biblico del matrimonio, w: A. M. Triacca, G. Pianazzi (red.), Realtà e valori del sacramento del matrimonio, Roma 1976, s 38; C. RYCHLICKI, Sakramentalny charakter przymierza małżeńskiego. Studium teologiczno dogmatyczne, dz. cyt. s. 97-99.

12 Por. N. M. Loss, Il tema biblico del matrimonio, dz. cyt., s. 39.
} 
„Wtedy podeszli do Niego uczniowie Jana i zapytali: «Dlaczego my i faryzeusze dużo pościmy, Twoi zaś uczniowie nie poszczą?» Jezus im rzekł: «Czy goście weselni mogą się smucić, dopóki pan młody (ho nymfios - Oblubieniec) jest z nimi?»” (Mt 9, 14-15) 13. Obecność Jezusa jako Oblubieńca obecnego na uczcie zostaje ukazana także w eschatologicznym aspekcie przypowieści o pannach roztropnych i nierozsądnych u Mateusza, gdzie Chrystus - Oblubieniec jest utożsamiony z Sędzią: „Gdy one szły kupić (oliwy), nadszedł pan młody [oblubieniec - ho nymfios]" (Mt 25, 10).

Wymienione tu przykłady wskazują, że starotestamentalna paralela przymierza miłości Boga z Izraelem w obrazie Oblubieniec - Oblubienica jest stosowana także w Nowym Testamencie dla wyrażenia analogicznej relacji przymierza miłości Chrystusa z nowym ludem Bożym, Kościołem. Podkreślona w obu opisach obecność Jezusa jako Oblubieńca na uczcie weselnej jest ukazana jako zapowiedź eschatologicznych godów, rozumianych jako moment nadziei i radości przy końcu świata. W ten sposób małżeństwo mężczyzny i kobiety zostaje ukazane także w relacji do miłości Chrystusa jako Oblubieńca.

To samo określenie Jezusa jako „Oblubieńca” występuje u św. Jana 3, 29. Ewangelista opisując prekursorską funkcję Jana Chrzciciela prezentuje ją w terminologii małżeńskiej: „Ten, kto ma oblubienicę jest oblubieńcem; a przyjaciel oblubieńca, który stoi i słucha go, doznaje najwyższej radości na głos oblubieńca” (J 3, 29).

W cytowanych perykopach została przez ewangelistów przywołana alegoria „małżeństwa z Chrystusem”, obecna w tamtych czasach. Jest to więc kontynuacja starotestamentalnego tematu o przymierzu małżeńskim Boga z Narodem wybranym. Natomiast w Apokalipsie znajdujemy odniesienie tej paraleli do Chrystusa i Kościoła w formie obrazu małżeństwa. Kościół przedstawiony jako „Święte Miasto”, „Nowe Jeruzalem”, zostaje tu ukazany w kategorii małżonki („nymfe”) oczekującej nadejścia Chrystusa, swego Pana jako męża („aner”), określonego mianem „Baranka Bożego” (por. Ap 21, 2-9).

13 Por. W. Günther, Matrimonio, w: Dizionario dei concetti biblici del Nuovo Testamento, Bologna 1989, s. 983. 
Częste stosowanie w pismach Nowego Testamentu terminów: „nymfios - nymfe” na określenie relacji Chrystusa do Kościoła, wyraża między nimi przymierze miłości. W takiej optyce przymierza wyjaśnia się lepiej również naturę małżeństwa mężczyzny i kobiety, które w Chrystusie i Kościele osiąga swój wymiar sakramentalny. Przy tak sformułowanym twierdzeniu jest uzasadnione pytanie: Na ile przymierze Chrystusa z Kościołem może być przyjęte jako archetyp miłości małżeńskiej, a następnie jako fundament dla sakramentalności małżeństwa?

Wielokrotnie stosowane w Nowym Testamencie terminy „nymfios - nymfe”, jako odpowiedniki określeń „Oblubieniec - Oblubienica”, dla przedstawienia relacji przymierza Chrystusa z Kościołem jako przymierza miłości, pomagają także w lepszym rozumieniu i wyjaśnianiu natury małżeństwa ludzkiego. Zgodnie z metodologiczną zasadą, według której „Stary Testament wyjaśnia się w Nowym”, należy rozumieć, że podobnie jak w Starym Testamencie określona terminologia pozwalała określać wewnętrzny związek między małżeństwem ludzkim i przymierzem Boga z Narodem wybranym, tak analogicznie w Nowym Testamencie stosowana terminologia staje się kluczem otwierającym możliwość postrzegania małżeństwa mężczyzny i niewiasty w przymierzu miłości Chrystusa z Kościołem, jako doskonałym modelem i źródłem małżeństwa ludzkiego i jego sakramentalności ${ }^{14}$.

Uznając tę analogię za właściwą, należy powiedzieć, że obecna w Nowym Testamencie idea przymierza odsyła do starotestamentalnej tradycji, według której przymierze jest paktem dwustronnym o charakterze oblubieńczym. W Starym Testamencie „przymierze Synaickie” było uważane za uroczyste zaślubiny Boga z Narodem wybranym. Stopniowo obraz przymierza został ubogacony dołączeniem uczty, związanej ze znakiem zaślubin (por. Jr 31,31), który występuje także w Nowym Testamencie jako element wzmacniający przymierze. Taki sens zostaje potwierdzony ucztą w Kanie Galilejskiej, gdzie

\footnotetext{
14 Por. C. Rychlicki, Sakramentalny charakter przymierza małżeńskiego. Studium teologiczno dogmatyczne, dz. cyt., s. 96-105.
} 
małżeństwo zawarte według pierwotnego modelu zostaje ubogacone obecnością Jezusa, nadającą małżeństwu charakter mesjański i sakramentalny (por. J 2,1-11) ${ }^{15}$. Podstawowym jednak tekstem wspomagającym chrześcijańską naukę o sakramentalności małżeństwa jest List do Efezjan (5, 21-33).

Perykopa ta zamyka w sobie dwie rzeczywistości zespolone wewnętrznie: kodeks postępowania członków rodziny i motywację doktrynalną $\mathrm{w}$ tej materii. W odniesieniu do instytucji małżeństwa istotny jest tekst Ef 5, 32: „Tajemnica to wielka, a ja mówię, w odniesieniu do Chrystusa i do Kościoła" (To mysterion touto mega estin, ego de lego eis Christon kai eis ten ecclesian).

Tekst ten stanowi przedmiot rozległych badań teologów w aspekcie sakramentalności małżeństwa, przez co wchodzi on w zakres wiedzy interdyscyplinarnej, zwłaszcza prawa kanonicznego. Istotna uwaga została skupiona na terminie „mysterion” (tajemnica), który Wulgata tłumaczy przez „misterium” albo „sacramentum”. W różnych miejscach występowania tego terminu w ewangeliach odnosi się on do tajemnicy zbawczej, kierowanej i realizowanej przez Chrystusa, jako przyczyny jedności ludu Bożego (Kościoła) z Bogiem. Według wielu autorów termin ten oznacza symboliczną relację między małżeństwem naturalnym i jednością Chrystusa z Kościołem. Takie rozumienie myśli św. Pawła miałoby swoje oparcie na występującym w perykopie Ef 5, 21-33 porównaniu dwóch rzeczywistości: małżeńskiej jedności mężczyzny i kobiety oraz jedności Chrystusa z Kościołem. Na to zdają się wskazywać zastosowane przez Apostoła partykuły: „hos” (jak) (w. 23), „hos - houtos” (tak jak) (w. 24), „houtos” (tak) (w. 28), „kathos” (jak) (w. 29) ${ }^{16}$.

Odwołując się do sceny powołania przez Stwórcę mężczyzny i kobiety do „jedności ciała” w małżeństwie (por. Rdz 2,24), jako przymierza miłości w relacji do przymierza Boga z Izraelem, termin

15 Por. C. Rychlicкi, Małżeństwo w Kościele katolickim, 2. Ujęcie systematyczne, p. 2, w: Encyklopedia Katolicka, t. 11, Lublin 2006, kol. 1067.

16 Por. H. Schlier, Der Brief an die Epheser, Zürich-Ensiedeln-Köln 1982, s. 253 -260. Por. Y. Congar, Kościół jako sakrament zbawienia, Warszawa 1980, s. 25-29. 
„mysterion” zastosowany przez św. Pawła w odniesieniu do przymierza: „Chrystus - Kościół” i „mężczyzna - niewiasta”, wskazywałby nie tylko na zwykły symbol, ale na ścisłą analogię obu przymierzy biblijnych i ich odniesienie do relacji przymierza miłości małżeńskiej z przymierzem miłości Chrystusa i Kościoła. W tym sensie Pawłowe „misterium”, użyte w Ef 5, 21-33, oznaczałoby, że tajemnica zawarta w Rdz 2, 24 jest wielka, bo osiągnęła swój zbawczy rozwój w relacji Chrystusa do Kościoła.

Tak więc zrealizowana, czyli objawiona przez Chrystusa wielkość tej tajemnicy („mysterion - misterium”), czyni z przymierza miłości Chrystusa do Kościoła rzeczywistą normę dla małżeńskiego przymierza mężczyzny i kobiety. Wielkość owego misterium („tajemnica to wielka”) wynika z „rzeczywistego odtwarzania” w małżeństwie ludzkim relacji miłości Chrystusa do Kościoła. Ponieważ relacja Chrystusa do Kościoła jest przymierzem miłości, na podobieństwo starotestamentalnego przymierza Boga z Narodem wybranym, to jej „rzeczywiste odtworzenie” w małżeństwie jest relacją miłości między mężem i żoną, zgodnie z wolą Stwórcy wyrażoną w akcie stworzenia ${ }^{17}$.

W oparciu o tak rozumianą przez św. Pawła relację małżeństwa do przymierza Chrystusa z Kościołem znany biblista R. Schnackenburg podkreśla: „Chrystus i Kościół są zatem nie tylko wzorem i modelem dla chrześcijańskiego małżeństwa, ale jednocześnie elementem istotnie określającym naturę małżeństwa i postępowanie małżonków w ich wzajemnym związku. Wiersz 32 (Ef 5, 21-32) jest więc interpretacją Rdz 2, 24 w świetle Chrystusa i Kościoła" ${ }^{18}$.

W świetle teologiczno-biblijnej analizy listu do Efezjan (5,21-32) należy wy prowadzić wniosek, że „małżeńst wo wyprowadzające swoją naturalną godność z aktu stworzenia, otrzymuje nowy sens teologiczny poprzez fakt udziału w «wielkim misterium», rozumianym

\footnotetext{
17 Por. R. BAtey, The mia Sarks Union of Christ and the Church, New Testament Studies 13 (1967), s. 270-281.

18 Por. R. Schnackenburg, Die Ehe im Neuen Testament, w: Theologie der Ehe, Regensburg 1969, s. 22.
} 
jako Boży plan zbawienia, odnoszący się do nowej społeczności wierzących". 19

Z owego „wielkiego misterium” małżeństwo naturalne wyprowadza swój szczególny wymiar, jakim jest „miłość Chrystusa”. Ponieważ ze związku Chrystusa z Kościołem małżeństwo wyprowadza swoją naturę, to w oparciu o Ef 5, 21-33 należy dodać, że miłość Chrystusa do Kościoła nie jest jedynie odwzorowana w małżeństwie naturalnym, ale „rzeczywiście odtworzona”. W ten sposób małżeństwo nie stanowi jedynie wyjątkowej rzeczywistości ziemskiej, ale rzeczywiście odtwarza w sobie nierozerwalne przymierze miłości Chrystusa z Kościołem, uczestnicząc w ten sposób w ekonomii zbawczej.

Skoro więc przymierze miłości między Bogiem i Izraelem, a następnie między Chrystusem i Kościołem, zostało wpisane w małżeńskie przymierze mężczyzny i kobiety, to małżeństwo jako dobry dar Stwórcy dla człowieka jest instytucją świętą i uświęcającą. Taki jego naturalny status nie może ograniczać się jedynie do uznawania jego godności, ale wyznacza on naturalne obowiązki względem samych małżonków i odpowiedzialność za rodzinę przez małżeństwo kształtowaną.

\section{Współczesne wyzwania dla małżeństwa i rodziny}

\subsection{Jedność i nierozerwalność związku małżeńskiego}

Jak już zostało wyżej przypomniane, starotestamentalne źródła Objawienia mówią wprost o powołaniu przez Stwórcę do istnienia człowieka na „obraz i podobieństwo Boga” w wydaniu mężczyzny i kobiety, by stali się oni „jednym ciałem”. Z psychologicznego punktu widzenia ukształtowanie się pary małżeńskiej z mężczyzny i kobiety dokonuje się na płaszczyźnie więzi emocjonalnej. Ukonstytuowanie się takiej relacji dwojga osób może mieć jednak zróżnicowane motywy, ale istotowo to sama natura tej relacji prowadzi do kształtowania

19 C. Rychlicki, Sakramentalny charakter przymierza małżeńskiego. Studium teologiczno-dogmatyczne, dz. cyt., s. 112. 
warunków trwałości i zdolności obu stron do wzajemnego zaangażowania na rzecz uformowanego związku. Należy jednak pamiętać o różnicach relacji, w jakich pozostają jej partnerzy, aby nie mylić związku ukształtowanego wyłącznie na bazie emocjonalnej z prawnie zawartym związkiem małżeńskim.

Partnerzy związku opartego jedynie na bazie emocjonalnej, mogącej wyrazić się także w relacjach seksualnych, najczęściej ograniczają się do idealizowania swoich doznań i wyobrażeń wobec drugiej strony. Relacja rzeczywistej miłości między nimi, zorientowanej na podjęcie wysiłku dla dobra obojga i kreowania rodziny, zamyka się przed podjęciem takiego wysiłku. Dzieje się tak, gdy nawet jedna strona nie jest zdolna zaakceptować drugiej bez zmiany własnych projekcji jej dotyczących. W takim związku dochodzi szybko do pęknięć, do niezdolności powstrzymania konfliktów, co w konsekwencji prowadzi do rozpadu. Jest to wynik zbyt przedmiotowego pojmowania drugiej strony, gdy myśląc o miłości do niej ma się w rzeczywistości na uwadze jedynie swoją własną jej wizję. Wynika to z błędu traktowania miłości jedynie na bazie uczuć. Miłość bowiem wspomaga w oczyszczeniu własnego spojrzenia i oceny siebie samego w pryzmacie drugiej strony. Zdolność włączenia własnej sfery uczuciowej w sferę miłości oznacza pragnienie wspólnego zaangażowania na rzecz kształtowania przyszłości. Na tym polega umiejętność odkrycia sensu miłości i jej właściwego rozumienia. Tego rodzaju postępowanie wymaga jednak dojrzałości ukształtowanej jeszcze w okresie przedmałżeńskim w wymiarze dojrzałości emocjonalnej, intelektualnej i seksualnej.

Aktualna rzeczywistość, odnotowująca wzrost separacji i rozwodów w małżeństwie, jest jasnym sygnałem wzywającym dla wzmożenia wysiłków, także duszpasterskich, o lepsze przygotowanie młodych do małżeństwa. Chodzi bowiem o dobro nie tylko pojedynczych osób, ale również o osłabienie kryzysu moralnego i kulturowego, dewastującego życie społeczne $e^{20}$.

\footnotetext{
20 Por. T. Anatrella, Le confusioni affettive e ideologiche che colpiscono le coppie contemporanee, w: Pontificio Consiglio Per la FAMiglia, Famiglia e questioni etiche, Bologna 2004, s. 53-66.
} 
Należy jasno powiedzieć, że taka troska o dobrze funkcjonujące małżeństwo i na nim opartą rodzinę, nie wypływa jedynie z pobudek religijnych, ale ma na uwadze ład społeczny i właściwie rozumiane dobro w wydaniu konkretnej osoby i społeczeństwa. W aspekcie religijnym małżeństwo i rodzina są rzeczywistością świętą i jednocześnie ludzką, zadaną człowiekowi z obowiązkiem troski o ich właściwy rozwój, bo w nich jest zawarta przyszłość ludzkości. Przyszłość ludzkości kształtuje się w głównej mierze poprzez dobrze funkcjonujące małżeństwo i rodzinę. Stąd też wyjątkowy walor posiada małżeństwo scalone, bo tylko takie będzie platformą właściwie formującą osoby w rodzinie, co stanowi ich wartość humanizującą i świadczącą o realizowanej odpowiedzialności za dobro drugiej osoby i społeczności, w której żyją.

W Adhortacji Apostolskiej „Familiaris consortio” Jan Paweł II mówi o miłości jako zasadzie i sile jedności między małżonkami i w rodzinie między jej członkami (por. FC, 18). Wobec poważnego problemu rozwodów Papież mówi o nierozerwalności małżeństwa: „Zakorzeniona w osobowym i całkowitym obdarowaniu się małżonków i wymagana dla dobra dzieci nierozerwalność małżeństwa znajduje swoją ostateczną prawdę w zamyśle Bożym, wyrażonym w Objawieniu" (FC, 20).

W Nowym Testamencie wartość źródłową dla tego przymiotu małżeństwa posiada Ef 5, 25 i Mt 19, 4-6. Jest to prawda zakorzeniona w świadomości człowieka od początku jego historii. Skoro więc małżeństwo zawarte między chrześcijanami ma rzeczywiście odtwarzać w sobie miłość Chrystusa do Kościoła, jako dar udzielony Kościołowi przez Chrystusa (por. Ef 5, 31-32), to musi być nierozerwalne. Na podobieństwo wolnego daru miłości udzielonej przez Chrystusa Kościołowi również małżonkowie w dniu ślubu składają sobie wzajemnie dar miłości wypowiadając słowa przysięgi: „Ślubuję ci miłość, wierność i uczciwość małżeńską oraz to, że cię nie opuszczę aż do śmierci” ${ }^{21}$.

21 Por. KKK, n. 1640: „Węzeł małżeński został więc ustanowiony przez samego Boga, tak że zawarte i dopełnione małżeństwo osób ochrzczonych nie może być 
W komentarzu do owego daru Chrystusowej miłości do Kościoła, odtworzonej w małżeństwie (por. Ef 5, 25-32), prof. H. Schlier tak pisze: „Małżeństwo, jako odtworzenie niebiańskiego małżeństwa Chrystusa z Kościołem zostało wyniesione do najwyższej godności [...]. Jemu, jako niebiańskiemu odtworzeniu małżeństwa Chrystusa z Kościołem, przynależy godność, która później została uznana jako «charakter sakramentalny». [...] W każdym małżeństwie ziemskim niezależnie od świadomości jaką posiadają o nim kontrahenci - zostaje odtworzona nie tylko relacja stworzenia Adama - Ewy, ale również relacja odkupienia: Chrystus - Kościół"22.

Pewną trudność egzegetyczną, która przenosi się na obszar teologii i prawa kanonicznego, stanowi tekst Mt 5, 31, w którym Chrystus w „Kazaniu na Górze” wyjaśniając swoją relację wobec Prawa stwierdza, że nie przyszedł na ziemię, aby znieść stare Prawo, ale je wypełnić (por. Mt 5, 17-20). Wyjaśniając szóste przykazanie „Nie cudzołóż”, odwołuje się On do dawnego Prawa, w którym powiedziano: „Jeśli kto chce oddalić swoją żonę, niech jej da list rozwodowy". W odniesieniu do takiego stylu daje On wyjaśnienie własne: „A Ja wam powiadam: «Każdy, kto oddala swoją żonę poza wypadkiem nierządu (parektos lógou porneías) - naraża ją na cudzołóstwo; a kto by oddaloną wziął za żonę, dopuszcza się cudzołóstwa»" (Mt 5, 31-32) ${ }^{23}$.

nigdy rozwiązane. Węzeł wynikający z wolnego, ludzkiego aktu małżonków i z dopełnienia małżeństwa jest odtąd rzeczywistością nieodwołalną i daje początek przymierzu zagwarantowanemu wiernością Boga. Kościół nie ma takiej władzy, by wypowiadać się przeciw temu postanowieniu mądrości Bożej”. Por. Franciszek, Adhortacja apostolska Amoris laetitiae, 19 III 2016, n. 62-63.

22 Por. H. Schlier, La lettera agli Efesini, Brescia 1973, s. 441.

23 Termin porneía, tłumaczony jako cudzołóstwo, jest różnie interpretowany w poszczególnych wyznaniach chrześcijańskich (związek nieważny lub cudzołożny), a także jako separacja. Por. X. LÉON-Dufour, Rozwód, w: Słownik Nowego Testamentu, Poznań 1986, s. 552-553; „Przymierze, które winno łączyć człowieka z Bogiem więzią wiernej miłości, jest przez proroków przedstawiane przy pomocy symbolu nierozerwalnego małżeństwa (Oz 2, 21n; Iz 54, 5n) [por. Oblubieniec]. Tak więc niewierność ludu napiętnują oni jako cudzołóstwo i nierząd $(\mathrm{Oz} 2,4)$, ponieważ lud oddaje się kultowi bałwanów jak nierządnica swym partnerom - dla 
Analizując ten tekst w kontekście starotestamentalnego przymierza Boga z Izraelem trzeba przyjąć, że uznanie cudzołóstwa za wystarczający motyw dla rozwodu byłoby głębokim zejściem w czas poprzedzający przymierze Boga z Narodem wybranym, jak to opisuje Ozeasz $(2,1-25)$. W tym sensie Jezus ustosunkował się do tego problemu w rozmowie z faryzeuszami, którzy chcąc Go wystawić na próbę postawili Mu pytanie, powołując się na praktykę „listu rozwodowego” wskazanego przez Mojżesza. W odpowiedzi usłyszeli oni: „Przez wzgląd na zatwardziałość serc waszych pozwolił wam Mojżesz oddalać wasze żony, lecz od początku tak nie było" (Mt 19, 8).

Ponieważ małżeństwo chrześcijańskie symbolizuje przymierze Boga z Izraelem, a następnie odtwarza w sobie przymierze miłości Chrystusa z Kościołem, to cudzołóstwo nie może stanowić motywu rozwodu ${ }^{24}$. Doktryna ta oznacza zastosowanie zasady monogamiczności małżeństwa do konkretnego związku zawartego między mężczyzną i kobietą. Od początku historii instytucję małżeństwa charakteryzują dwa istotne przymioty: jedność i nierozerwalność. W małżeństwie chrześcijańskim otrzymują one wzmocnienie przez wyniesienie przez Chrystusa naturalnego związku mężczyzny i kobiety do godności sakramentu ${ }^{25}$.

korzyści (Oz 2, 7; 4, 10; Jer 5, 7; 13. 27; Ez 23, 42 n; Iz 57, 3). Jezus podejmuje ten obraz dla potępienia niedostatku wiary. Nazywa „plemieniem wiarołomnym” niedowiarków, żądających znaków i niewierzących, którzy wstydzą się Jego i Jego Ewangelii [...]. Przez to potępienie dostrzegamy jaśniej absolutną wierność jako równorzędną z wymaganiem miłości”. M. F. LACAN, w: X. LÉon-Dufour, Słownik Teologii Biblijnej, Poznań - Warszawa 1982, s. 170-171.

24 Por. K. H. Menke, Sacramentalita'. Essenza e ferite del cattolicesimo, Brescia 2015, s. 89; J. RatzInger, Zur Theologie der Ehe, Theologische Quartalschrift 149 (1969) s. 65; C. RYchlicki, Bóg jest miłością. Refleksja nad encykliką Benedykta XVI, Płock 2006, s. 13-18.

25 Por. KPK, kan. 1056: „Istotnymi przymiotami małżeństwa są jedność i nierozerwalność, które w małżeństwie chrześcijańskim nabierają szczególnej mocy z racji sakramentu”; także KPK, kan. $1055 \$ 1$. 


\subsection{Małżeństwo w sytuacji kulturowego kryzysu i duszpasterskie wyzwania}

Jakkolwiek żadna epoka nie jest całkowicie wolna od problemów dotyczących małżeństwa i rodziny, to w naszych czasach ten problem stał się wprost alarmujący. Analizując różne sytuacje, w jakie on jest włączony, widać wyraźnie, że w postępujących przemianach w małżeństwie i w życiu codziennym problem dotyczy przede wszystkim formacji ludzkiej. To powoduje, że mnożące się problemy odnoszą się do istoty małżeństwa i życia. Styl życia i postępowanie wielu osób $\mathrm{w}$ konkretnych sytuacjach nie koresponduje $\mathrm{z}$ obrazem instytucji małżeńskiej, powołanej przez Stwórcę dla jej dobra i rozwoju innych osób, z którymi małżeństwo jest genetycznie związane. Nie będzie przesadą stwierdzenie, że wiele form postępowania w codziennym życiu wskazuje na dehumanizację osoby. Świadczy o tym kryzys poprawnego rozumowania i kryzys wartości, a to prowadzi do upadku osoby, która często nie zdaje sobie sprawy z niebezpieczeństwa, w jakim się obraca i dokąd zmierza ${ }^{26}$.

Jednym z wymiarów charakteryzujących zjawiska deformujące małżeństwo i rodzinę jest polityka kulturowa, wyrażająca się w głośnej formie w wielu parlamentach i na płaszczyznach międzynarodowych, które wywierają negatywny wpływ na opinię publiczną. Chodzi tu głównie o prawodawstwo, które kontrastuje z prawem naturalnym. $\mathrm{W}$ imię demokracji i pluralizmu propaguje się relatywizm etyczny. Na taką sytuację często reagował Jan Paweł II, odwołując się do sumienia polityków i prawodawców ${ }^{27}$.

W wielu ogłoszonych deklaracjach w materii małżeństwa widać, że „prawda obiektywna” zostaje po prostu definiowana wolą i decyzją podjętą przez większość parlamentarną. W sytuacji, gdy małżeństwo i rodzina są pojmowane w określeniach odmiennych od prawa naturalnego, wszystko wydaje się być usprawiedliwione i godziwe.

\footnotetext{
26 Por. Jan PaweŁ II, Encyklika Evangelium vitae, 25 III 1993, n. 95-96.

27 Por. Jan PaweŁ II, Encyklika Veritatis splendor, 6 VIII 1993, n. 97; Tenże, Encyklika Evangelium vitae, dz. cyt., n. 13, 27, 72 i 90.
} 
Taka sama postawa odnosi się do prawa do życia w zakresie aborcji, inżynierii genetycznej itd ${ }^{28}$.

Wobec dokonujących się przemian w sprawach tak istotnych dla życia jednostki i ładu społecznego, jakim jest problem małżeństwa i rodziny, aktualnie stał się głośny na płaszczyźnie duszpasterskiej problem osób „rozwiedzionych i powtórnie zawierających cywilny związek małżeński”. Na tej płaszczyźnie pojawił się duszpasterski problem względem osób pozostających w takim związku, a pragnących przystępować do Komunii świętej. Problem ten należy rozważać w świetle „prawdy” objawionej przez Chrystusa, która powinna stać u podstaw duszpasterskiej troski Kościoła. Taka troska została wyrażona jasno w naszych czasach w adhortacji Jana Pawła II „Familiaris consortio”. Dokument ten podkreśla różne aspekty duszpasterstwa rodzin, zwracając szczególną uwagę na trudne sytuacje w naszych czasach, a wymagające wyjątkowej delikatności, jasności i roztropności wobec osób w nich uczestniczących. Odnosi się to w szczególny sposób do osób rozwiedzionych i pozostających w nowych związkach cywilnych ${ }^{29}$.

Ten problem w naszych czasach powinien stanowić wyjątkowe także wyzwanie dla duszpasterstwa Kościoła: „Kościół bowiem ustanowiony dla prowadzenia wszystkich ludzi, a zwłaszcza ochrzczonych, do zbawienia, nie może pozostawić swemu losowi tych, którzy - już połączeni sakramentalną więzią małżeńską - próbowali zawrzeć nowe małżeństwo. Będzie też niestrudzenie podejmował wysiłki, by oddać im do dyspozycji posiadane przez siebie środki zbawienia" ${ }^{30}$.

W oparciu o jakie przesłanki należy realizować tak przedstawione wskazania duszpasterskie względem osób pozostających w skomplikowanych sytuacjach małżeńskich? Motywem duszpasterstwa

\footnotetext{
28 Por. A. López Trujillo, Le nuove sfide della famiglia e della vita. La pastorale familiare e i matrimoni in difficoltà, w: PONTIFICIO CONSIGLIO PER LA FAMIGLia, Famiglia e questioni etiche, Bologna 2004, s. 67-73.

29 Por. Jan PaweŁ II, Adhortacja apostolska Familiaris consortio, 22 XI 1981, cz. IV, szczególnie n. 83-84.

30 Tamże, n. 84.
} 
osób rozwiedzionych i pozostających w nowych związkach jest ich „status kościelny”. Właśnie z ich „statusu kościelnego” wynikają ich „prawa i obowiązki” wobec Kościoła, i odwrotnie: „prawa i obowiązki” Kościoła wobec osób rozwiedzionych i pozostających w nowych związkach.

Sytuacja kościelna tych osób jest regulowana podwójną linią postępowania:

1. Osoby rozwiedzione i pozostające w nowych związkach są nadal członkami Kościoła;

2. Osoby rozwiedzione i pozostające w nowych związkach nie pozostają w pełni koniecznej wspólnoty kościelnej.

W odniesieniu do każdej z tych form wypływa usprawiedliwiona i konieczna forma duszpasterstwa kościelnego.

Trwanie członkostwa kościelnego osób rozwiedzionych i będących w nowym związku wypływa wprost z otrzymanego chrztu i pośrednio $\mathrm{z}$ trwania $\mathrm{w}$ wierze chrześcijańskiej. Jak wiadomo, chrzest „wyciska” trwały charakter sakramentalny, włączając w Chrystusa i Jego Kościół. W tej sytuacji także rozwód i zawarcie nowego związku nie są w stanie dokonać ontologicznej zmiany w osobie ochrzczonej. Odnośnie zachowania wiary przez osoby rozwiedzione trzeba dodać, że nawet utrata wiary w nierozwiązywalność węzła małżeńskiego nie prowadzi w sposób konieczny do utraty wiary w inne prawdy chrześcijańskie. W tym świetle osoby raz ochrzczone, mimo zerwania ważnie zawartego małżeństwa i pozostające w nowym związku, nie tracą swej przynależności do Kościoła. W oparciu o taką sytuację osoby rozwiedzione i pozostające w nowym związku mogą uczestniczyć w życiu i misji Kościoła, odpowiednio do ich sytuacji kościelnej, o czym mówi Papież Jan Paweł II w Adhortacji „Familiaris consortio”, precyzując jednocześnie ich prawa: „Wzywam gorąco pasterzy i całą wspólnotę wiernych do okazywania pomocy rozwiedzionym, do podejmowania z troskliwą miłością starań o to, by nie czuli się oni odłączeni od Kościoła, skoro mogą, owszem, jako ochrzczeni, powinni uczestniczyć w jego życiu. Niech będą zachęcani do słuchania Słowa Bożego, do uczęszczania na Mszę świętą, do wytrwania w modlitwie, do pomnażania dzieł miłości oraz inicjatyw wspólnoty 
na rzecz sprawiedliwości, do wychowania dzieci w wierze chrześcijańskiej, do pielęgnowania ducha i czynów pokutnych, ażeby w ten sposób z dnia na dzień wypraszali sobie u Boga łaskę" ${ }^{31}$.

Druga linia duszpasterskiego posługiwania odnosi się do „osób rozwiedzionych i pozostających w nowym związku”, które trwając w tym stanie nie uczestniczą w koniecznej „pełni jedności z Kościołem". Owo ograniczenie oznacza, że osoby rozwiedzione i pozostające w nowym związku pozostają w sprzeczności z Ewangelią Chrystusa i z Kościołem, które wymagają od chrześcijan wierności w małżeństwie i jego nierozerwalności. Pozostając w takiej sytuacji osoby, o których mowa, doznają pewnego ograniczenia swoich praw kościelnych, nie z powodu nałożenia tych ograniczeń przez Kościół, ale wynikających z ich sytuacji życiowej. Ograniczenia te dotykają głównie widzialnej sfery przyjmowania sakramentów, zwłaszcza Eucharystii $^{32}$.

Można rozumieć przykre uczucie osób, które znalazły się w sytuacji uniemożliwiającej przystąpienie do Komunii eucharystycznej, a w dalszym ciągu są wrażliwe na problemy religijne. Motyw kierujący odmowę udzielenia Komunii osobom rozwiedzionym i pozostającym w nowym związku został teologicznie wyjaśniony w adhortacji „Familiaris consortio”: „Kościół na nowo potwierdza swoją praktykę, opartą na Piśmie Świętym, niedopuszczanie do komunii eucharystycznej rozwiedzionych, którzy zawarli ponowny związek małżeński. Nie mogą być dopuszczeni do komunii świętej od chwili, gdy ich stan i sposób życia obiektywnie zaprzeczają tej więzi miłości między Chrystusem i Kościołem, którą wyraża i urzeczywistnia Eucharystia. Jest poza tym inny szczególny motyw duszpasterski: dopuszczenie do Eucharystii wprowadzałoby wiernych w błąd lub powodowałoby zamęt co do nauki Kościoła o nierozerwalności małżeństwa" ${ }^{33}$.

Druga wypowiedź tego dokumentu zwraca uwagę na duszpasterskie stanowisko Kościoła odnośnie do relacji: „sakramenty a osoby

\footnotetext{
31 Tamże, n. 84.

32 Por. D. Tettamanzi, La Famiglia via della Chiesa, Milano 1991, s. 281-296

33 Jan PaweŁ II, Adhortacja apostolska Familiaris consortio, dz. cyt., n. 84.
} 
rozwiedzione i pozostające w nowych związkach w określonych sytuacjach". Osąd o dopuszczalności do sakramentu Eucharystii mógłby zależeć od dwóch czynników, które mogą wpływać na postępowanie duszpasterskie, a zależą od zmiany życiowej sytuacji osób rozwiedzionych i pozostających nadal w nowym związku z powodu określonych motywów. Jeden z nich dotyczyłby osób rozwiedzionych, które dokonały separacji fizycznej albo pozostają w nowym związku dla ściśle określonego celu. W tym przypadku wymieniony dokument Kościoła tak precyzuje: „Pojednanie w sakramencie pokuty - które otworzyłoby drogę do komunii eucharystycznej - może być dostępne jedynie dla tych, którzy żałując, że naruszyli znak Przymierza i wierności Chrystusowi, są jeszcze gotowi na taką formę życia, która nie stoi w sprzeczności z nierozerwalnością małżeństwa. Oznacza to konkretnie, że gdy mężczyzna i kobieta, którzy dla ważnych powodów - jak na przykład wychowanie dzieci - nie mogąc uczynić zadość obowiązkowi rozstania się, postanawiają żyć w pełnej wstrzemięźliwości, czyli powstrzymywać się od aktów, które przysługują jedynie małżonkom" 34 .

Analizując duszpasterskie wysiłki Kościoła, można w nich odczytać, że zdając sobie sprawę z poważnego naruszenia, czy nawet zanegowania w pewnych przypadkach źródłowej wartości małżeństwa, Kościół szuka jeszcze sposobów niesienia pomocy osobom przeżywającym dramat a zachowującym wiarę, by w granicach ostatecznych możliwości pomóc im przezwyciężyć ciężar dramatu. Należy to rozumieć jako pedagogię Bożego miłosierdzia dla podtrzymania osoby ludzkiej w kryzysie. Tego rodzaju duszpasterskie wysiłki są wyrazem świadczenia przez Kościół o wartości człowieka i chrześcijańskiego małżeństwa. Głos Kościoła w tej materii stanowi także wezwanie dla odpowiedzialnego przygotowania kandydatów do małżeństwa ze strony duszpasterzy, a samych kandydatów do odwagi i wysiłku na rzecz pokonywania trudności i kryzysów.

\footnotetext{
34 Tamże, n. 84. Por. Franciszek, Adhortacja apostolska Amoris laetitiae, dz. cyt., n. 296-300.
} 


\section{Zakończenie}

Ścisły związek między antropologicznym i teologicznym wymiarem małżeństwa wyzwala serię problemów i wymogów w kluczu etyki chrześcijańskiej. Małżeństwo jako dobry dar Stwórcy udzielony człowiekowi w akcie stworzenia (por. $\mathrm{Rdz} 1,26-27$ ) jest instytucją naturalną i zarazem wyniesioną przez Chrystusa do godności sakramentu. W ten sposób stanowi on przedmiot badań nauk świeckich i teologicznych, łącznie z prawem kanonicznym. W wymiarze instytucji naturalnej w Starym Testamencie jest on symbolem przymierza miłości Boga z Izraelem, co stanowi o jego wielkości, a jednocześnie stanowi odpowiedzialne wyzwanie do współpracy w dziele stwórczym z Bogiem (por. Rdz 1, 28). Z rozwojem historii, jako uprzywilejowane dzieło Stwórcy małżeństwo jest przedmiotem szczególnej uwagi Jezusa Chrystusa, który rozwija jego znaczenie i wartość w kluczu nowego przymierza miłości między Chrystusem i Kościołem. W przekazie św. Pawła małżeństwo już nie tylko symbolizuje przymierze miłości człowieka z Bogiem, ale stanowi „rzeczywiste odtworzenie” tego przymierza miłości (por. Ef 5, 31-32). W ten sposób małżeństwo powołane przez Stwórcę na początku historii, osiąga w przymierzu miłości Chrystusa z Kościołem (nowym Ludem Bożym), swój wymiar sakramentalny, jako instytucja „odtwarzająca miłość” Boga do człowieka. Ta wyjątkowa wartość stanowi dla mężczyzny i kobiety, zjednoczonych w małżeństwie, wymóg wierności i trwałości ich przymierza, na wzór przymierza miłości Boga z człowiekiem. Tradycja chrześcijańska na przestrzeni wieków odnotowuje w materii jedności i nierozwiązywalności małżeństwa przykłady ich wiernego przestrzegania i zarazem drastycznego od nich odchodzenia. Przemiany kulturowe w naszej epoce wyraźnie wskazują na drastyczne zmiany w instytucji małżeństwa i rodziny, które nie tylko w wymiarze religijnym, ale także naturalnym, prowadzą do dehumanizacji osoby ludzkiej. Niszczenie małżeństwa i rodziny, jako podstawowej bazy społeczeństwa, prowadzi wprost do jego osłabienia i degradacji w wymiarze kulturowym i egzystencjalnym. 


\section{The identity of sacramental mystery in the covenant between Christ and Church and marriage covenant}

\section{Summary}

A close connection between anthropological and theological dimension of marriage triggers a series of problems and requirements in the key of Christian ethics. Marriage as a good gift from the Creator, granted in the divine act of creation (cf. Genesis 1, 26-27), is a natural institution raised by Christ to the dignity of a sacrament. As a result, it constitutes a research subject of both secular and theological sciences, including canon law. As a natural institution, in the Old Testament it is a symbol of the covenant of God's love to Israel, which confirms its greatness and at the same time is a challenge to cooperate in the act of creation with God (cf. Genesis 1, 28). With time, as a privileged creation of the Creator, marriage received special attention of Jesus Christ, who developed its meaning and importance in the key of new covenant of love between Christ and Church. In the message of St. Paul, marriage not only symbolizes the covenant of God's love to humans, but is also "a realistic renewal" of this covenant of love (cf. Ephesians 5, 31-32). Thereby, marriage created by the Creator at the beginning of history, reaches in the covenant between Christ and Church (new God's people) its sacramental dimension as an institution "reconstructing" God's love to humans. This unique value constitutes for a man and woman, united in marriage, a requirement of faithfulness and permanence of their covenant, modeled of the covenant of God's love to humans. As far as the unity and indissolubility of marriage is concerned, over the centuries the Christian tradition has taken note of a number of examples of faithful obedience and drastic failure to comply with the rules of marriage. Cultural changes in our century clearly indicate drastic changes in the institution of marriage and family, not only in religious, but also natural dimension and lead to dehumanization of the human person. The destruction of marriage and family as fundamental units of society, leads to its impairment and degradation in cultural and existential aspect. 